\title{
PERANCANGAN SISTEM INFORMASI AKUNTANSI DENGAN PERSPEKTIF ISLAM
}

\author{
Ujang Muhamad Hidayatuloh
}

Yayasan Pendidikan Sosial Islam Darul Amal Jampangkulon

Kampung Selajati RT/RW 02/01 Ds. Bojonggenteng, Kec. Sukabumi

Email: ujang.mh@gmail.com

Abstract

This research is literacy research by title 'Designing of Accountance Information System in Islamic Perspective'. The aim of the research is trying to understand of planning accountance system in Islamic view'. In this writing by using qualitative method in descriptive approach. Islamic perspective was applied in internal controlling as core of accountance information system. Internal control component were affected include accounting policies, controlling and supervising activities. The main information consists of financial report which fulfilled of accountance information system application such as Microfost Office Excel is very essential. That application output are both financial position report and activity report that accordance with PSAK 45. Islamic perspective is used in deep internal control not only responsible to human being an sich but also responsible to vertical dimension, the God, Alloh swt.

Keywords: designing, accounting information system, islam

Abstrak

Penelitian ini adalah penelitian studi pustaka yang mengambil judul "Perancangan Sistem Informasi Akuntansi dengan Perspektif Islam". Tujuan penelitian ini adalah untuk mengetahui bagaimana prancangan informasi akuntansi dengan menggunakan perspektif Islam. Jenispenelitian yang digunakan dalam penelitian ini adalah penelitian kualitatif dengan pendekatan deskriptif. Perspektif Islam diterapkan pada pengendalian internal yang merupakan induk sistem informasi 
akuntansi. Komponen pengendalian internal yang dipengaruhinya antara lain kebijakan akuntansi, aktivitas pengendalian dan pengawasan. Adapun kebutuhan informasi yang berupa laporan keuangan, dipenuhi oleh aplikasi sistem informasi akuntansi yang dirancang menggunakan Microsoft Office Excel. Output aplikasi tersebut adalah laporan posisi keuangan dan laporan aktivitas yang sesuai dengan PSAK 45. Perspektif Islam menjadikan pengendalian internal tidak semata-mata dilakukan hanya sebagai bentuk pertanggungjawaban kepada manusia saja, lebih dari pada itu agar dapat pula dipertanggungjawabkan dihadapan Allah Swt.

Kata kunci: perancangan, sistem informasi akuntansi, islam

\section{PENDAHULUAN}

Islam merupakan agama paripurna yang mengatur seluruh aspek kehidupan manusia termasuk yang berkaitan dengan pengelolaan keuangan. Dalam sebuah entitas, pendapatan dan beban harus dapat dipertanggungjawabkan baik itu di dunia maupun di akhirat sebagaimana sabda Nabi SAW.

"Kedua kaki seorang hamba tidak akan bergeser pada hari kiamat sampai ditanya tentang empat perkara; tentang umurnya untuk apa dia habiskan, tentang masa mudanya untuk apa dia gunakan, tentang hartanya darimana dia peroleh dan kemana dia infakkan dan tentang ilmunya apa saja yang telah dia amalkan." (HR At Tirmidzi)

Sedemikian beratnya tanggung jawab yang harus dipikul, sehingga orang yang diberi tanggung jawab mengelola keuangan, dalam pelaksanaannya harus dibantu dengan sebuah sistem pengendalian internal agar tidak melakukan hal-hal yang salah.

Syariah Islam juga berperan dalam pengendalian internal yang merupakan induk dari sistem informasi akuntansi. Orang yang menjalankan agama Islam dengan sungguh-sungguh tidak perlu diawasi dalam melakukan sebuah pekerjaan karena telah menjadikan Allah Swt. sebagai pengawas utamanya. Namun demikian kadang kala iman seseorang itu melemah, sehingga pengawasan dengan sistem yang dirancang sedemikian rupa dapat membantu menjaganya dari perbuatan tidak terpuji (penyelewengan dan kecurangan).

Perancangan sistem informasi akuntansi dengan perspektif Islam akan menentukan arah kebijakan akuntansi suatu entitas baik itu bisnis maupun nirlaba. Kebijakan tersebut memengaruhi proses pengumpulan data yang menjadi input suatu sistem informasi akuntansi, yang mana menurut Hall (2009:17) "dalam banyak hal, pengumpulan data merupakan tahapan yang paling penting dalam sistem". Sehingga, jika pada saat proses pengumpulan data tersebut salah atau ada yang disembunyikan, maka informasi yang dihasilkannya pun (output) otomatis akan salah dan menyesatkan. 


\section{PEMBAHASAN}

\section{Pengendalian Internal}

Pengendalian internal menurut Mulyadi (2001:163) meliputi "struktur organisasi, metode dan ukuran-ukuran yang dikoordinasikan untuk menjaga kekayaan organisasi, mengecek ketelitian dan keandalan data akuntansi, mendorong efisiensi dan mendorong dipatuhinya kebijakan manajemen."

Menurut Elder, dkk. (2011:318) "kerangka pengendalian internal yang digunakan di hampir seluruh perusahaan AS adalah kerangka terintegrasi-pengendalian internal dari Committee of Sponsoring Organization of the Treadway Comission (COSO)."Kerangka terintegrasi-pengendalian internal dari COSO tersebut memiliki 5 komponen (Elder, dkk., 2011:321-333) yaitu:

\section{Lingkungan Pengendalian}

Lingkungan pengendalian terdiri dari tindakan, kebijakan dan prosedur yang menggambarkan keseluruhan sikap manajemen, direksi, dan pemilik dari suatu entitas atas pengendalian internal dan pentingnya pengendalian internal tersebut terhadap entitas. Untuk memahami dan menilai pengendalian lingkungan, harus mempertimbangan beberapa subkomponen berikut:

\section{Integritas dan Nilai Etika}

Integritas dan nilai-nilai etika merupakan produk dari standar etika dan sikap sebuah entitas. Integritas dan nilai-nilai etika mencakup tindakan manajemen untuk menghilangkan kesenjangan yang dapat mendorong personel berlaku tidak jujur serta komunikasi mengenai nilai yang dianut oleh entitas dan standar perilaku kepada setiap personel melalui pernyataan kebijakan, kode etik dan keteladanan.

\section{Komitmen terhadap Kompetensi}

Kompetensi merupakan pengetahuan dan keterampilan yang dibutuhkan untuk mengerjakan tugas-tugas yang diberikan. Komitmen terhadap kompetensi mencakup pertimbangan manajemen terhadap tingkat kompetensi untuk pekerjaan tertentu.

\section{Partisipasi Dewan Direksi dan Komisaris atau Komite Audit}

Dewan direksi dan komite audit harus ikut serta dalam melakukan pengawasan dan bersikap independen terhadap manajemen untuk memastikan bahwa manajemen telah melakukan pengendalian internal dan proses pelaporan keuangan yang tepat. 


\section{Filosofi Manajemen dan Gaya Operasi}

Dengan memahami filososfi manajemen dan gaya operasi yang tergambarkan dalam aktivitas mereka dapat dilihat bagaimana sikap manajemen terhadap pengendalian internal.

\section{Struktur Organisasi}

Struktur organisasi akan menggambarkan jalur tanggung jawab dan otorisasi dalam suatu entitas. Dengan memahami struktur organisasi yang ada dapat dipahami bagaimana berjalannya pengendalian internal pada entitas tersebut.

\section{Kebijakan dan Praktik Sumber Daya Manusia}

Aspek yang paling penting dalam pengendalian internal adalah karyawan. Karyawan yang jujur dan kompeten tidak membutuhkan banyak pengendalian, akan tetapi bisa saja motivasi mereka berubah karena pengaruh dari luar maupun dari internal diri mereka sendiri. Dengan demikian dibutuhkan metode perekrutan, evaluasi, pelatihan, promosi, dan pemberian kompensasi yang baik agar karyawan yang dihasilkan merupakan karyawan pilihan.

\section{Penilaian Risiko}

Penilaian risiko untuk laporan keuangan merupakan identifikasi dan analisis manajemen terhadap risiko-risiko yang relevan terhadap penyusunan laporan keuangan sesuai dengan prinsip akuntansi yang berlaku umum.

\section{Aktivitas Pengendalian}

Aktivitas pengendalian merupakan kebijakan dan prosedur, selain yang telah dimasukkan dalam keempat komponen lainnya, yang membantu untuk meyakinkan bahwa tindakan-tindakan yang penting telah dilakukan untuk mengatasi risiko-risiko dalam mencapai tujuan organisasi.

Aktivitas pengendalian yang umum dilakukan antara lain: (1) Pemisahan tugas yang memadai. (2) Otorisasi yang tepat atas transaksi dan aktivitas. (3) Dokumentasi dan catatan yang memadai. (4) Pengendalian fisik atas aset dan catatan-catatan. (5) Pengecekkan terhadap pekerjaan secara independen.

\section{Informasi dan Komunikasi}

Tujuan dari sistem informasi dan komunikasi akuntansi suatu entitas adalah untuk memulai, mencatat, memproses dan melaporkan transaksi-transaksi yang terjadi dalam suatu entitas dan untuk menjaga akuntabilitas aset-aset yang terkait. 


\section{Pengawasan}

Aktivitas pengawasan berkaitan dengan penilaian yang berjalan atau penilaian berkala atas kualitas pengendalian internal oleh manajemen untukmenentukan bahwa pengendalian dijalankan sesuai dengan tujuannya dan dimodifikasi jika diperlukan yaitu jika terjadi perubahan kondisi.

Tujuan umum pengendalian internal menurut American Institut of Certified Public Accountant (AICPA) Professional Standards dalam Hall (2009:181) adalah: (a) Menjaga aset perusahaan. (b) Memastikan akurasi dan keandalan catatan serta informasi akuntansi. (c) Mendorong efisiensi dalam operasional perusahaan. (d) Mengukur kesesuaian dengan kebijakan serta prosedur yang ditetapkan oleh pihak manajemen.

\section{Kebijakan Akuntansi}

Definisi kebijakan akuntansi berdasarkan paragraf 5 PSAK 25 tentang Kebijakan Akuntansi, Perubahan Estimasi Akuntansi, dan Kesalahan (revisi 2009) adalah "prinsip, dasar, konvensi, peraturan, dan praktik tertentu yang diterapkan entitas dalam penyusunan dan penyajian laporan keuangan."

Adapun ketentuan pemilihan dan penerapan kebijakan akuntansi diatur lebih lanjut dalam paragraf 7-12 PSAK 25 yang dapat dijelaskan sebagai berikut: (a) Menggunakan PSAK tertentu, jika ada PSAK yang secara spesifik mengatur suatu transaksi, peristiwa atau kondisi lainnya. (b) Menggunakan pertimbangan manajemen, jika tidak ada PSAK yang secara spesifik mengatur suatu transaksi dengan syarat dapat menghasilkan informasi yang: (1) Relevan untuk kebutuhan pengambilan keputusan ekonomi pengguna, dan (2) Andal, dengan kriteria: (a) Menyajikan secara jujur posisi keuangan, kinerja keuangan dan arus kas. (b) Mencerminkan substansi ekonomi transaksi, peristiwa, atau kondisi lainnya, dan bukan hanya bentuk hukum. (c) Netral, yaitu bebas dari bias. (d) Pertimbangan sehat. (e) Lengkap dalam semua hal yang material. (c) Dalam mempertimbangkan kebijakan akuntansi, manajemen harus memperhatikan penerapan: (1) Persyaratan dan panduan dalam SAK yang berhubungan dengan masalah serupa dan terkait. (2) Definisi, kriteria pengakuan, dan konsep pengukuran untuk aset, liabilitas, penghasilan, dan beban dalam kerangka dasar penyusunan laporan dan penyajian laporan keuangan. (d) Manajemen juga harus mempertimbangkan standar akuntansi terkini yang dikeluarkan oleh badan penyusun standar akuntansi lain yang menggunakan kerangka dasar yang sama untuk mengembangkan standar akuntansi, literatur akuntansi lain, dan praktik akuntansi industri yang berlaku sepanjang tidak bertentangan dengan SAK utama. 


\section{Sistem Informasi Akuntansi}

\section{Pengertian Sistem}

Sistem adalah kelompok dari dua atau lebih komponen atau subsistem yang saling berhubungan yang berfungsi dengan tujuan yang sama (Hall, 2009:6). Dari pengertian tersebut dapat dipahami bahwa suatu sistem itu terdiri dari: (1) beberapa komponen, (2) antar komponen tersebut harus memiliki keterkaitan dan saling bekerja sama, (3) bekerja untuk mencapai suatu tujuan yang sama, dan (4) suatu sistem merupakan subsistem dari sistem lain yang lebih besar, yang menurut Hall (2009:7) "tergantung dari perspektif mana kita melihatnya."

\section{Pengertian Informasi}

Informasi adalah data yang diproses (diedit, diringkas, atau diperbaiki) yang menyebabkan pengguna mengambil keputusan (Hall, 2009:15). Menurut definisi tersebut Hall (2009:15) juga menyimpulkan bahwa "data yang sudah diproses tidak menjadi informasi jika tidak menggerakkan penggunanya untuk mengambil keputusan atau tindakan."

\section{Pengertian Akuntansi}

Jusup (2011:5) mendefinisikan akuntansi dengan dua sudut pandang yang berbeda, yaitu dilihat dari sudut pandang pengguna dan proses akuntansi. Dilihat dari sudut pandang pengguna, akuntansi didefinisikan sebagai suatu disiplin yang menyediakan informasi yang diperlukan untuk melaksanakan kegiatan secara efisien dan mengevalusi kegiatan-kegiatansuatu entitas. Sedangkan dari sudut pandang proses, akuntansi didefinisikan sebagai kegiatan yang terdiri dari pencatatan, penggolongan, peringkasan dan penganalisisan data keuangan suatu entitas.

Berdasarkan beberapa pengertian parsial di atas, Mulyadi (2001:3) mendefinisikan sistem akuntansi sebagai organisasi formulir, catatan, dan laporan yang dikoordinasikan sedemikian rupa untuk menyediakan informasi keuangan yang dibutuhkan oleh manajemen guna memudahkan pengelolaan perusahaan.

Dapat disimpulkan bahwa suatu sistem informasi akuntansi bertugas mengumpulkan dan menyeleksi data transaksi keuangan yang bersumber dari formulir atau catatan-catatan kemudian mengolahnya menjadi informasi berupa laporan keuangan atau laporan-laporan lainnya yang berguna sebagai bahan pertimbangan manajemen untuk menentukan keputusan apa yang akan diambil berdasarkan pada informasi tersebut. Selain itu, laporan keuangan yang dihasilkan sistem informasi juga dijadikan sebagai laporan pertanggungjawaban kepada pihak-pihak yang berkepentingan (stakeholder). 


\section{Model Umum Sistem Informasi Akuntansi}

Model Umum Sistem Informasi Akuntansi yang digambarkan oleh Hall (2009: 15-21) adalah sebagai berikut:

\section{Pengguna Akhir}

Pengguna akhir (end user) dibagi ke dalam dua kelompok umum: eksternal dan internal. Pengguna ekternal meliputi para kreditor, pemegang saham, calon investor, lembaga pemerintahan, kantor pajak, pemasok, danpelanggan. Pengguna internal meliputi pihak manajemen di tiap tingkat dalam perusahaan, serta personil operasional.

\section{Sumber Data}

Sumber data (data source) adalah berbagai transaksi keuangan yang masuk ke dalam sistem informasi baik dari sumber internal maupun eksternal. Transaksi keuangan eksternal adalah berbagai pertukaran ekonomi dengan berbagai entitas bisnis dan individu lain di luar perusahaan. Sedangkan transaksi keuangan internal melibatkan pertukaran atau perpindahan sumber daya dalam perusahaan.

\section{Pengumpulan Data}

Pengumpulan data (data collection) adalah tahap operasional pertama dalam sistem informasi. Tujuannya adalah memastikan bahwa data kegiatan yang masuk ke dalam sistem valid, lengkap, dan bebas dari kesalahan.

\section{Pemrosesan Data}

Setelah selesai dikumpulkan, data diproses untuk menghasilkan informasi.

\section{Manajemen Basis Data}

Basis data (data base) perusahaan adalah tempat penyimpanan fisik data keuangan dan nonkeuangan. Manajemen basis data (database management) melibatkan tiga pekerjaan dasar: penyimpanan, penarikan, dan penghapusan.

\section{Pembuatan Informasi}

Pembuatan informasi (information generation) adalah proses menyusun, mengatur, memformat, dan menyajikan informasi ke para pengguna. Informasi yang berguna memiliki karakteristik sebagai berikut (Hall, 2009:19-20): (1) Relevan: Isi dari suatu informasi harus sesuai dengan tujuan. (2) Tepat waktu: Informasi harus tersedia pada saat dibutuhkan. (3) Akurasi: Informasi harus bebas dari kesalahan yang signifikan (4) Kelengkapan: Semua informasi yang penting bagi sebuah 
keputusan atau pekerjaan harus tersedia. (5) Ringkas: Informasi yang tersedia harus sesuai dengan kebutuhan pengguna. (g) Umpan balik (feedback).

Umpan balik (feedback) adalah suatu bentuk output yang dikirim kembali ke sistem sebagai sumber data. Umpan balik dapat berasal dari sumber internal maupun ekternal dan berguna untuk memulai atau mengubah proses.

\section{Tujuan Sistem Informasi Akuntansi}

Hall (2009:21) menyatakan "terdapat tiga tujuan dasar yang umum didapati di semua sistem," yaitu: (a) Mendukung fungsi penyediaan (stewardship) pihak manajemen. Sistem informasi menyediakan informasi mengenai penggunaan sumber daya perusahaan melalui laporan keuangan maupun laporan lainnya yang diwajibkan oleh regulator. (b) Mendukung pengambilan keputusan pihak manajemen. Sistem informasi menyediakan informasi yang menjadi dasar bagi pengambilan keputusan manajemen. (c) Mendukung operasional harian perusahaan. Sistem informasi menyediakan informasi yang dapat meningkatkan efektifitas dan efisiensi tenaga operasional dalam suatu entitas.

\section{Sistem Akuntansi Pokok}

Unsur sistem akuntansi pokok menurut Mulyadi (2001:3) antara lain:

\section{Formulir}

Mulyadi (2001:75) mendefinisikan formulir sebagai "secarik kertas yang memiliki ruang untuk diisi." Mulyadi (2001:3) juga menjelaskan bahwa fungsi formulir adalah untuk "merekam terjadinya transaksi."

Dalam merancang suatu formulir, Mulyadi (2001:82) menetapkan beberapa prinsip dalam proses pembuatannya. Prinsip-prinsip tersebut antara lain: (1) Memanfaatkan tembusan atau copy formulir. (2) Menghindari duplikasi dalam pengumpulan data. (3) Merancang formulir sesederhana dan seringkas mungkin. (4) Memasukkan unsur internal check dalam merancang formulir. (5) Menyantumkan nama dan alamat perusahaan pada formulir yang akan digunakan untuk komunikasi dengan pihak luar. (6) Memberikan nama pada formulir untuk memudahkan identifikasi. (7) Memberi nomor untuk identifikasi formulir. (8) Menyantumkan nomor garis pada sisi sebelah kiri dan kanan formulir, jika formulir lebar digunakan, untuk memperkecil kemungkinan salah pengisian. (9) Membuat garis pada formulir, jika formulir tersebut akan diisi dengan tulisan tangan. Jika pengisian dilakukan dengan alat, mesin atau komputer garis tersebut tidak diperlukan. (10) Menyantumkan nomor urut tercetak. (11) Merancang formulir tertentu sedemikian rupa sehingga pengisi hanya membubuhkan tick mark (tanda tertentu), atau dengan menjawab YA/ TIDAK untuk menghemat waktu pengisiannya. (12) Menyusun formulir ganda 
dengan menyipkan karbon, atau dengan mencetaknya langsung pada kertas yang tidak memerlukan karbon (carbonless paper) untuk penggandaan. (13) Membagi zona sedemikian rupa sehingga formulir dibagi menurut blok-blok daerah yang logis yang berisi data yang saling terkait.

Adapun manfaat formulir menurut Mulyadi (2001:78) antara lain: (1) Menetapkan tanggung jawab timbulnya transaksi bisnis perusahaan. (2) Merekam data transaksi bisnis perusahaan. (3) Mengurangi kemungkinan kesalahan dengan cara menyatakan semua kejadian dalam bentuk tulisan. (4) Menyampaikan informasi pokok dari orang satu ke orang lain di dalam organisasi yang sama atau ke organisasi lain.

\section{Jurnal}

Jurnal merupakan catatan akuntansi pertama yang digunakan untuk mencatat, mengklasifikasikan, dan meringkas data keuangan dan data lainnya. Sumber informasi pencatatan adalah formulir. (Mulyadi, 2001:4).

Prinsip-prinsip dasar yang melandasi perancangan jurnal menurut Mulyadi (2001: 104) adalah sebagai berikut: (1) Harus tersedia jurnal dalam jumlah yang memadai sehingga memungkinkan perusahaan untuk menggunakan karyawan dalam mencatat dengan segera transaksi keuangan yang terjadi. (2) Jurnal akan digunakan untuk memisahkan transaksi ke dalam penggolongan pokok tertentu, seperti penerimaan kas, pengeluaran kas, penjualan dan pembelian. (3) Untuk mengurangi pekerjaan pembukuan yang terinci, harus digunakan kolom-kolom khusus dalam jurnal, sehingga memungkinkan pembukuan (posting) jumlah per kolom ke dalam rekening yang bersangkutan di dalam buku besar. (4) Nama kolom dalam jurnal harus sesuai dengan nama rekening yang bersangkutan dalam buku besar, yang akan menerima jumlah yang akan dibukukan dari jurnal. (5) Kolom-kolom dalam jurnal digunakan untuk mengumpulkan angka yang akan diringkas dalam rekening yang bersangkutan dalam buku besar. (6) Sedapat mungkin jurnal harus dirancang sedemikian rupa sehingga pekerjaan menyalin informasi dari dokumen sumbernya dibuat sangat minimum. (7) Harus ditetapkan hubungan antara dokumen sumber tertentu dengan jurnal sehingga pertanggungjawaban kebenaran informasi dapat ditentukan.

\section{Buku Besar dan Buku Pembantu}

Buku besar (general ledger) merupakan kumpulan rekening-rekening yang digunakan untuk menyortasi dan meringkas informasi yang telah dicatat dalam jurnal. Sedangkan buku pembantu (subsidiary ledgers) adalah suatu cabang buku besar yang berisi rincian rekening tertentu yang ada dalam buku besar (Mulyadi, 2001:121).

Proses sortasi dan pemindahan data ke dalam buku besar dan buku pembantu disebut dengan pembukuan (posting) (Mulyadi, 2001:122). Menurut Mulyadi (2001: 
122) dalam sistem manual, kegiatan posting ini memerlukan 4 tahap berikut: (1) Pembuatan rekapitulasi jurnal. (2) Penyortasian rekening yang akan diisi dengan data rekapitulasi. (3) Pencatatan data rekapitulasi dalam rekening yang bersangkutan.

(4) Pengembalian rekening ke dalam arsip pada urutannya semula.

Baik buku besar maupun buku pembantu terdiri dari rekening. Rekeningrekening yang dibentuk dalam buku besar harus disesuaikan dengan jenis dan susunan informasi yang akan disajikan dalam laporan keuangan (Mulyadi, 2001:127). Biasanya laporan keuangan yang dipakai sebagai dasar pembentukkan dan penyusunan rekening-rekening pada buku besar adalah laporan posisi keuangan dan laporan rugi laba.

Untuk kemudahan identifikasi, rekening-rekening tersebut kemudian diberi kode. Menurut Mulyadi (2001:127) "kode adalah suatu rerangka (framework) yang menggunakan angka atau huruf atau kombinasi angka dan huruf untuk memberi tanda terhadap klasifikasi yang sebelumnya telah dibuat."

Terdapat 5 (lima) metode pemberian kode rekening (Mulyadi, 2001:129):

\section{Kode Angka atau Alfabet Urut (numerical or alphabetic sequence code)}

Dalam metode ini, kode rekening buku besar diberi kode angka atau huruf yang berurutan. Kelemahan metode pengkodean ini adalah jika terjadi perluasan jumlah rekening, maka keseluruhan kode rekening yang mempunyai kode angka lebih besar mengalami perubahan.

\section{Kode Angka Blok (block numerical code)}

Dalam metode ini, rekening buku besar dikelompokkan menjadi beberapa golongan dan setiap golongan disediakan satu blok angka yang berurutan untuk memberi kodenya. Untuk menghadapi kemungkinan perluasan rekening, dalam setiap blok angka disediakan angka cadangan perluasan, sehingga perluasan kode rekening hanya akan mempengaruhi pemberian kode rekening dalam blok yang bersangkutan.

\section{Kode Angka Kelompok (group numerical code)}

Kode angka kelompok terbentuk dari dua atau lebih subcodes yang dikombinasikan menjadi satu kode. Kode angka kelompok ini mempunyai karakteristik sebagai berikut: (a) Rekening diberi kode angka atau kombinasi angka dan huruf. (b) Jumlah angka dan/atau huruf dalam kode adalah tetap. (c) Posisi angka dan/atau huruf dalam kode mempunyai arti tertentu. (d) Perluasan klasifikasi dilakukan dengan memberi cadangan angka dan/atau huruf ke kanan. 


\section{Kode Angka Desimal (decimal code)}

Kode angka desimal memberi kode angka terhadap klasifikasi yang membagi kelompok menjadi maksimum 10 subkelompok dan membagi subkelompok menjadi maksimum 10 golongan yang lebih kecil dari subkelompok tersebut.

\section{Kode Angka Urut Didahului dengan Huruf (numerical sequence preceded by an alphabetic reference)}

Metode ini menggunakan kode berupa kombinasi angka dengan huruf. Setiap rekening diberi kode angka yang di mukanya dicantumkan huruf singkatan kelompok rekening tersebut.

\section{Laporan}

Hasil akhir sistem informasi adalah laporan keuangan. Agar dapat diperbandingkan, laporan tersebut harus sesuai dengan standar yang berlaku umum di suatu tempat. Adapun standar akuntansi keuangan yang berlaku di Indonesia yang mengatur tentang pelaporan keuangan entitas nirlaba adalah PSAK 45. Pada paragraf 1 standar tersebut dijelaskan bahwa entitas yang dapat menerapkan PSAK 45 pada laporan keuangannya adalah yang memenuhi karakteristik berikut: (1) Sumber daya entitas nirlaba berasal dari pemberi sumber daya yang tidak mengharapkan pembayaran kembali atau manfaat ekonomi yang sebanding dengan jumlah sumber daya yang diberikan. (2) Menghasilkan barang dan/atau jasa tanpa bertujuan memupuk laba, dan jika entitas nirlaba menghasilkan laba, maka jumlahnya tidak dibagikan kepada pendiri atau pemilik entitas nirlaba tersebut. (3) Tidak ada kepemilikan seperti umumnya pada entitas bisnis, dalam arti bahwa kepemilikan dalam entitias nirlaba tidak dapat dijual, dialihkan, atau ditebus kembali, atau kepemilikan tersebut tidak mencerminkan proporsi pembagian sumber daya entitas nirlaba pada saat likuidasi atau pembubaran entitas nirlaba. Unsur-unsur yang harus ada dalam laporan entitas nirlaba menurut paragraf 9 PSAK 45 tentang Pelaporan Keuangan Entitas Nirlaba adalah: (1) laporan posisi keuangan pada akhir periode laporan, (2) laporan aktivitas, dan (3) laporan arus kas untuk suatu periode pelaporan, serta (4) catatan atas laporan keuangan. Perbedaan mendasar laporan keuangan entitas nirlaba dengan organisasi berorientasi laba adalah dengan tidak adanya laporan laba rugi yang diganti dengan laporan aktivitas dan laporan perubahan ekuitas karena organisasi nirlaba dalam hal ini yayasan tidak dimiliki oleh seseorang.

\section{Metodologi Pengembangan Sistem Akuntansi}

Metodologi pengembangan sistem adalah langkah-langkah yang dilalui oleh analis sistem dalam mengembangkan sistem informasi (Mulyadi, 2001:39). Masih 
menurut Mulyadi (2001:39), pengembangan sistem akuntansi dilaksanakan melalui tiga tahap utama berikut ini:

\section{Analisis Sistem (system analysis)}

Analisis sistem dibagi menjadi empat tahap:

\section{Analisis Pendahuluan}

Analisis pendahuluan digunakan untuk mengetahui gambaran menyeluruh mengenai aktivitas atau operasi suatu entitas. Hasil analisis ini akan berguna untuk menyusun usulan pelaksanaan analisis sistem.

\section{Penyusunan Usulan Pelaksanaan Analisis Sistem}

Usulan pelaksanaan sistem merupakan dokumen yang digunakan untuk menyamakan persepsi antara analis sistem dan pemakai sistem tentang apa yang dibutuhkannya dan pengembangan yang akan dilakukan oleh analis.

Menurut Mulyadi (2001: 43), dokumen tersebut menjelaskan beberapa hal berikut: (a) Alasan yang mendasari pengembangan sistem. (b) Pernyataan tentang persyaratan kinerja yang diharapkan dari sistem akuntansi. (c) Batasan luas analisis sistem. (d) Identifikasi informasi yang dibutuhkan untuk analisis sistem. (e) Identifikasi sumber-sumber informasi yang diperlukan untuk analisis sistem. (f) Daftar kejadian penting (milestone) dan target waktu penyelesaian untuk memonitor perkembangan analisis sistem.

\section{Pelaksanaan Analisis Sistem}

Pelaksanaan analisis sistem melalui tahapan-tahapan berikut (Mulyadi, 2001: 46-49):

\section{Analisis Laporan Yang Dihasilkan Sekarang}

Tahapan ini berguna untuk menilai laporan yang dihasilkan oleh sistem yang ada saat ini dan menemukan informasi yang kurang yang dibutuhkan oleh manajemen namun tidak bisa dihasilkan oleh sistem tersebut.

\section{Menganalisis Transaksi}

Pada tahapan ini analis sistem melaksanakan analisis terhadap setiap transaksi meliputi analisis terhadap formulir, catatan, dan prosedur yang digunakan dalam transaksi tersebut. Untuk setiap transaksi yang dilaksanakan perusahaan, analis sistem mengumpulkan informasi mengenai: (i) Unit organisasi yang terkait dalam transaksi. (ii) Formulir yang digunakan. (iii) Sistem otorisasi dalam pelaksanaan 
transaksi. (iv) Catatan akuntansi yang digunakan untuk mencatat transaksi. (v) Prosedur pelaksanaan transaksi

\section{Mempelajari Catatan Pertama}

Catatan pertama dalam sistem akuntansi adalah jurnal. Analis sitem akan memeriksa apakah terdapat kelemahan pada jurnal-jurnal yang ada sekarangkemudian mempertimbangkan kemungkinan perancangan kembali jurnal tersebut atau menggantinya dengan jurnal-jurnal baru.

\section{Mempelajari Catatan Terakhir}

Buku besar merupakan catatan akhir dari sistem akuntansi. Sama halnya seperti jurnal, buku besar juga diperiksa apakah terdapat kelemahan atau tidak untuk kemudian analis sistem mempertimbangkan untuk merancang kembali buku besar atau menggantinya dengan rancangan baru.

\section{Penyusunan Laporan Hasil Analisis Sistem}

Hasil akhir analisis sistem disajikan dalam laporan hasil analisis sistem. Menurut Mulyadi (2001:50) isi laporan ini meliputi: (a) Pernyataan kembali alasan yang mendasari dan luas analisis sistem yang dilakukan analis sistem. (b) Daftar masalah besar yang ditemukan oleh analis sistem. (c) Pernyataan persyaratan informasi yang diperlukan oleh pemakai sistem. (d)Pernyataan tentang asumsi penting yang dibuat oleh analis sistem. (e) Proyeksi sumber daya yang diperlukan beserta biaya yang dibutuhkan dalam perancangan sistem akuntansi baru atau pengembangan sistem yang ada. (f) Rekomendasi analis sistem akan sistem yang diusulkan.

\section{Desain Sistem (system design)}

Desain sistem dibagi ke dalam lima tahap pelaksanaan (Mulyadi, 2001:51-53):

\section{Desain Sistem Secara Garis Besar}

Dalam tahap ini analis sistem menyajikan beberapa alternatif desain sistem informasi yang memungkinkan pemakai informasi memilih diantara berbagai desain sistem yang ditawarkan oleh analis sistem. Desain sistem secara garis besar tersebut terdiri dari desain masing-masing unsur blok bangunan sistem informasi yang meliputi desain keluaran, masukan, model, basis data dan pengendalian.

\section{Penyusunan Usulan Desain Sistem Secara Garis Besar}

Usulan desain sistem secara garis besar berisi informasi tertulis mengenai: (a) Pernyataan mengenai alasan dilakukannya pengembangan sistem. (b) Penyajian 
berbagai alternatif sistem informasi yang dikembangkan untuk memenuhi kebutuhan informasi. (c) Sumber daya yang diperlukan untuk mengimplementasikan dan mempertahankan masing-masing alternatif sistem. (d) Asumsi-asumsi kritis atau masalahmasalah yang mungkin berdampak terhadap desain final sistem.

\section{Evaluasi Sistem}

Dalam tahap evaluasi sistem, analis sistem menentukan persyaratan yang harus dipenuhi oleh blok teknologi dalam menjalankan sistem informasi yang dirancang.

\section{Penyusunan Laporan Final Desain Sistem secara Garis Besar}

Setelah salah satu alternatif desain sistem secara garis besar terpilih, analis sistem kemudian membuat laporan final desain sistem secara garis besar.

\section{Desain Sistem Secara Rinci}

Dalam tahap ini analis sistem melakukan desain rinci terhadap masing-masing blok bangunan sistem informasi menjadi bangunan sistem informasi yang mampu memenuhi kebutuhan informasi para pemakai.

\section{Penyusunan Laporan Final Desain Sistem Secara Rinci}

\section{Implementasi Sistem (system implementation)}

Tahapan-tahapan impelementasi sistem adalah sebagai berikut (Mulyadi, 2001: 54-56):

\section{Persiapan Implementasi Sistem}

Sebelum sistem baru diimplementasikan, terlebih dahulu dilakukan perencanaan penggunaan sistem baru. Hal ini dilakukan agar sistem baru tersebut tidak kontra produktif dengan sistem yang sudah berjalan sebelumnya. Sistem baru diharapkan mampu memenuhi kebutuhan informasi yang lebih baik dibanding sistem lama.

\section{Pendidikan dan Pelatihan Karyawan}

Pendidikan dan pelatihan karyawan mutlak diperlukan jika akan mengimplementasikan sebuah sistem baru. Karyawan tersebut dibagi ke dalam dua golongan yaitu karyawan pemakai informasi dan karyawan pengguna sistem. Pelatihan ini ditujukan kepada karyawan pengguna sistem agar dapat mengerti tentang tanggung jawabnya dan manfaat yang dapat diperoleh dari sistem tersebut. 


\section{Konversi Sistem}

Perubahan dari sistem lama ke sistem baru memerlukan pendekatan konversi tertentu. Menurut Mulyadi (2001:55) terdapat empat pilihan utama pendekatan dalam konversi sistem: (a) Konversi langsung, mengimplementasikan secara langsung sistem baru dan menghentikan segera pemakaian sistem lama. (b) Konversi paralel, mengimplementasikan sistem baru berbarengan dengan mempertahankan pemakaian sistem lama akan tetapi sampai batas waktu tertentu saja. (c) Konversi modular, implementasi sistem baru ke dalam organisasi secara parsial kepada bagianbagian tertentu terlebih dahulu. (d) Konversi phase-in, implementasi sistem baru dengan menerapkan sistem secara parsial.

\section{Tujuan Umum Pengembangan Sistem Akuntansi}

Menurut Mulyadi (2001:19-20) tujuan umum pengembangan sistem akuntansi adalah sebagai berikut: (a) Untuk menyediakan informasi bagi pengelolaan kegiatan usaha baru. (b) Untuk memperbaiki informasi yang dihasilkan oleh sistem yang sudah ada, baik mengenai mutu, ketepatan penyajian, maupun struktur informasinya. (c) Untuk memperbaiki pengendalian akuntansi dan pengecekan intern, yaitu untuk memperbaiki tingkat keandalan (reliability) informasi akuntansi dan untuk menyediakan catatan lengkap mengenai pertanggungjawaban dan perlindungan kekayaan perusahaan. (d) Untuk mengurangi biaya klerikal dalam penyelenggaraan catatan akuntansi.

\section{Perspektif Islam dalam Perancangan Sistem Informasi Akuntansi}

Sistem informasi akuntansi merupakan salah satu komponen pengendalian internal yang menghasilkan informasi untuk pengambilan keputusan. Bersama-sama dengan komponen pengendalian internal lainnya seperti struktur organisasi, kebijakan, pemisahan tugas, dan pengawasan, sistem informasi akuntansi bertujuan untuk menjaga aset organisasi agar dapat dipertanggungjawabkan kepada pihak-pihak yang berkepentingan. Dalam Islam, pertanggungjawaban itu tidak hanya di hadapan manusia saja, melainkan harus pula dapat dipertanggungjawabkan di hadapan Allah SWT. Sabda Rasulullah SAW. yang diriwayatkan oleh Tirmidzi menggambarkan pertanggungjawaban atas aset tersebut.

"Kedua kaki seorang hamba tidak akan bergeser pada hari kiamat sampai ditanya tentang empat perkara; tentang umurnya untuk apa dia habiskan, tentang masa mudanya untuk apa dia gunakan, tentang hartanya darimana dia peroleh dan kemana dia infakkan dan tentang ilmunya apa saja yang telah dia amalkan." (HR At Tirmidzi)

Oleh karena sedemikian beratnya pertanggungjawaban atas aset tersebut, maka proses pengendalian internal perlu dirancang sedemikian rupa agar dapat mencegah penyelewengan dan kecurangan. 


\section{Sistem Informasi Akuntansi}

Dalam dunia Islam, Al Khawarizmy berkontribusi besar dengan mendokumentasikan sistem akuntansi dan pencatatan pada negara Islam (Nurhayati dan Wasilah, 2009:57). Ada tujuh hal khusus dalam sistem akuntansi yang dijalankan oleh negara Islam menurut penjelasan Al Khawarizmi dan Al Mazendarany, yaitu: (a) Sistem akuntansi untuk kebutuhan hidup, sistem ini di bawah koordinasi seorang manajer. Sistem ini dapat digunakan perorangan, negara maupun sektor privat terutama untuk perhitungan zakat. (b) Sistem akuntansi untuk konstruksi, pada sistem ini diatur pencatatan, pendendalian dan akuntabilitas untuk masing-masing proyek berdasarkan anggaran. (c) Sistem akuntansi untuk pertanian yang memfokuskan pada pencatatan dan pengelolaan persediaan pertanian untuk keperluan perhitungan zakat tanpa memisahkan fungsi pencatatan dan pemegang persediaan. (d) Sistem akuntansi gudang merupakan sistem untuk mencatat pembelian barang negara. Pada sistem ini ditemukan pemisahan tugas antara orang yang memegang barang dan yang mencatat sebagai bentuk pengendalian. (e) Sistem akuntansi mata uang yang memberikan hak kepada pengelolanya untuk mengubah emas dan perak yang diterima pengelola menjadi koin sekaligus mendistribusikannya. Sistem akuntansi ini dijalankan dengan 3 jurnal khusus, yaitu untuk mencatat persediaan, pendapatan, dan beban. (f) Sistem akuntansi peternakan, pencatatan dalam sistem ini dilakukan untuk mencatat keluar dan masuknya ternak berdasarkan pengelompokkan binatang serta nilai uang. (g) Sistem akuntansi perbendaharaan merupakan sistem untuk mencatat penerimaan dan pengeluaran harian negara baik dalam nilai uang atau barang. Mekanisme pencatatannya, barang dan uang masuk dicatat di sisi kanan serta barang dan uang keluar dicatat di sisi sebelah kiri.

Pencatatan dalam negara Islam telah memiliki prosedur yang wajib diikuti. Jika ditemukan kesalahan dalam pencatatan sehingga menyebabkan ketidakseimbangan, maka orang yang diberi tanggung jawab harus menggantinya. Prosedur pencatatan tersebut antara lain: (a) Transaksi harus dicatat setelah terjadinya. (b) Transaksi harus dikelompokkan berdasarkan jenisnya. (c)Penerimaan dicatat di sebelah kanan dan pengeluaran dicatat di sebelah kiri, sumber-sumber penerimaan harus dijelaskan dan dicatat. (d) Pembayaran harus dicatat dan diberikan penjelasan yang memadai di sisi kiri halaman. (e) Pencatatan transaksi harus dilakukan dan dijelaskan secara hati-hati. (f) Tidak diberikan jarak penulisan di sisi sebelah kiri, dan harus diberi garis penutup. (g) Koreksi atas transaksi yang telah dicatat tidak boleh dengan cara menghapus atau menulis ulang, akan tetapi harus diganti. (h) Memberikan tanda pada akun yang telah ditutup. (i) Seluruh transaksi yang dicatat di buku jurnal akan dipindahkan pada buku khusus berdasarkan pengelompokkan transaksi. (j) Orang yang melakukan pencatatan untuk pengelompokkan berbeda dengan orang yang melakukan pencatatan harian. (k) Saldo diperoleh dari selisih. (l) Laporan harus disusun setiap bulan dan setiap tahun. Laporan harus cukup 
detail dan memuat informasi yang penting. (m) Pada setiap akhir tahun, laporan yang disampaikan oleh al Katib harus menjelaskan seluruh informasi secara detail barang dan dana yang berada di bawah wewenangnya. (n) Laporan tahunan yang disusun al Katib akan diperiksa dan dibandingkan dengan tahun sebelumnya dan akan disimpan di kantor pusat.

Beberapa jenis laporan keuangan yang dipraktikkan pada masa kejayaan Islam antara lain (Nurhayati dan Wasilah, 2009:60-61): (a) Al Khitmah: merupakan laporan yang dibuat setiap akhir bulan yang menunjukkan total penerimaan dan pengeluaran. (b) Al Khitmah al Jami'ah: merupakan laporan yang disiapkan oleh al Katib tahuanan dan diberikan kepada atasannya yang berisi pendapatan, beban, dan surplus/defisit setiap akhir tahun. (c) Perhitungan dan laporan zakat yang dikelompokkan menjadi 3 kelompok, yaitu: (1) Ar raj minal mal (yang dapat tertagih). (2) Al munkasir minal mal (piutang tidak dapat tertagih). (3) Al muta'adhir wal mutahayyir wal muta'akkid (piutang yang sulit dan piutang bermasalah sehingga tidak tertagih).

Adapun beberapa prinsip sistem keuangan Islam sebagaimana diatur dalam alQuran dan asSunah (Nurhayati dan Wasilah, 2009:84-85) antara lain: (a) Pelarangan riba. (b) Pembagian risiko. (c) Tidak menganggap uang sebagai modal potensial kecuali digunakan bersamaan dengan sumber daya yang lain untuk menghasilkan laba. (d) Larangan melakukan kegiatan spekulatif, sama halnya dengan melakukan transaksi yang memiliki tingkat ketidakpastian yang tinggi. (e) Kontrak atau perjanjian harus dipandang sebagai sesuatu yang suci (tinggi nilainya) sehingga seluruh kewajiban dan pengungkapan yang terkait dengan kontrak harus dilakukan. (f) Aktivitas usaha harus sesuai tuntunan syariah.

\section{Pengawasan}

Menurut Mannan dalam Hafiduddin dan Tanjung (2003:152) pengawasan dalam pandangan Islam dilakukan untuk meluruskan yang tidak lurus, mengoreksi yang salah, dan mebenarkan yang hak. Selanjutnya, pengawasan dalam ajaran Islam paling tidak terbagi menjadi dua hal (Hafiduddin dan Tanjung, 2003:156), yaitu:

\section{Pengawasan (Kontrol) dari Dalam Diri Sendiri yang Bersumber dari Tauhid dan Keimanan Kepada Allah}

Pengawasan yang berdasarkan kepada keimanan seseorang berasal dari keyakinannya terhadap doktrin atau pedoman agama yang dianutnya, dalam konteks Islam berarti al Quran dan Hadits. Salah satu firman Allah yang menyatakan pengawasan-Nya terhadap makhluknya adalah QS. Al Mujadalah: 7 yang artinya.

"Tidakkah kamu perhatikan, bahwa Sesungguhnya Allah mengetahui apa yang ada di langit dan di bumi? tiada pembicaraan rahasia antara tiga orang, melainkan Dia-lah keempatnya. dan tiada (pembicaraan antara) lima orang, melainkan Dia-lah 
keenamnya. dan tiada (pula) pembicaraan antara jumlah yang kurang dari itu atau lebih banyak, melainkan Dia berada bersama mereka di manapun mereka berada. kemudian Dia akan memberitahukan kepada mereka pada hari kiamat apa yang telah mereka kerjakan. Sesungguhnya Allah Maha Mengetahui segala sesuatu."

Orang yang menyadari bahwa dirinya selalu diawasi oleh Allah SWT tidak perlu lagi diawasi oleh siapa pun. Di dalam dirinya terpatri rasa takut kepada Allah SWT karena setiap apa yang dilakukannya kelak akan dimintai pertanggunjawaban di akhirat.

\section{Pengawasan (Kontrol) dari Luar, Yaitu Pengawasan yang Dilakukan oleh Sebuah Sistem pada Suatu Oraganisasi}

Sistem pengawasan yang baik menurut (Hafiduddin dan Tanjung, 2003:158) adalah pengawasan yang telah built in ketika menyusun sebuah program. Artinya, dalam menyusun sebuah program harus sudah ada unsur kontrol di dalamnya. Tujuannya adalah agar seseorang yang melakukan sebuah pekerjaan merasa bahwa pekerjaannya itu diperhatikan oleh atasan, bukan pekerjaan yang tidak diacuhkan atau dianggap enteng.

Pengawasan dari luar dimaksudkan untuk mencegah terjadinya penyalahgunaan atau penyelewengan apabila sewaktu-waktu hawa nafsu seseorang mengalahkan pertahanan dirinya yang berupa tauhid dan iman. Karena adakalanya tingkat keimanan seseorang itu menurun dan ada kalanya pula naik, sebagaimana firman Allah SWT dalam QS. Al Fath: 4 yang menyatakan iman itu bisa naik:

"Dia-lah yang telah menurunkan ketenangan ke dalam hati orang-orang mukmin supaya keimanan mereka bertambah di samping keimanan mereka (yang telah ada). dan kepunyaan Allah-lah tentara langit dan bumi dan adalah Allah Maha Mengetahui lagi Maha Bijaksana."

Dalam proses pengawasan, tidak hanya ditekankan kepada kegiatan mengawasi saja melainkan harus ada tindak lanjut berupa kegiatan mengoreksi. Dengan demikian orang yang salah tidak dibiarkan melakukan kesalahannya secara terus menerus baik itu karena unsur ketidaktahuan atau kesengajaan, akan tetapi harus segera diingatkan agar meninggalkan pekerjaan yang salah tersebut kemudian mengarahkannya untuk melakukan pekerjaan yang benar atau melakukan pekerjaan dengan benar.

Dengan mengacu kepada QS. Al Balad: 17 dan QS. Al Ashr: 3, Hafiduddin dan Tanjung (2003: 160) mendasarkan koreksi terhadap suatu kesalahan kepada 3 hal: (a) Tawashau bil haqqi (saling menasihati atas dasar kebenaran dan norma yang jelas), artinya menasihati dengan dasar telah adanya aturan yang jelas yang disepakati bersama. (b) Tawashau bis shabri (saling menasihati atas dasar kesabaran). Adakalanya seseorang itu mengulang kesalahan-kesalahan yang pernah dilakukannya, sehingga nasihat atau koreksi pun perlu dilakukan secara berulang-ulang, dan 
dalam proses tersebut diperlukan kesabaran. (c) Tawashau bil marhamah (saling menasihati atas dasar kasih sayang). Maksudnya adalah, pengawasan dilakukan dengan dasar kasih sayang agar orang yang diawasi tidak terjerumus ke dalam sesuatu yang salah yang dapat merugikan dirinya sendiri.

\section{SIMPULAN}

Berdasarkan hasil penelitian, dapat disimpulkan bahwa YAPSI Darul 'Amal termasuk yayasan yang sudah memenuhi kriteria Pasal 52 Undang-Undang Nomor 16 Tahun 2001 jo. Undang-Undang Nomor 28 Tahun 2004 tentang Perubahan Undang-Undang Nomor 16 tentang Yayasan yang salah satunya adalah menerima bantuan sebesar Rp 500.000.000,00 atau lebih dalam 1 tahun buku. Dengan demikian, sesuai dengan undang-undang pula, laporan keuangan YAPSI Darul' Amal harus disusun menggunakan standar akuntansi keuangan yang berlaku di Indonesia dan diaudit oleh akuntan publik. Oleh karena laporan keuangan YAPSI Darul 'Amal belum sesuai dengan tuntutan undang-undang tersebut, maka keberadaan sebuah sistem informasi akuntansi sangat dibutuhkan agar dapat menghasilkan laporan keuangan yang sesuai dengan standar.

Perancangan sistem informasi akuntansi YAPSI Darul 'Amal dengan perspektif Islam mempengaruhi proses pengendalian internal yang merupakan induk sistem informasi akuntansi. Komponen pengendalian internal yang dipengaruhinya antara lain kebijakan akuntansi, aktivitas pengendalian dan pengawasan. Perspektif Islam menjadikan pengendalian internal tidak semata-mata dilakukan hanya sebagai bentuk pertanggungjawaban kepada manusia saja, lebih dari pada itu agar dapat pula dipertanggungjawabkan di hadapan Allah Swt.

Adapun kebutuhan informasi yang berupa laporan keuangan sebagai bahan pertanggungjawaban dan dasar pengambilan keputusan, dipenuhi dengan dirancangnya aplikasi sistem informasi akuntansi menggunakan Microsoft Office Excel. Out put aplikasi tersebut adalah laporan posisi keuangan dan laporan aktivitas.

\section{DAFTAR PUSTAKA}

Al Quran

Hadits

Basrowi, Suwandi. 2008. Memahami Penelitian Kualitatif. Jakarta: Rineka Cipta. Dewan Standar Akuntansi Keuangan. 2009. PSAK No. 25 (revisi 2009): Kebijakan Akuntansi, Perubahan Estimasi Akuntansi, dan Kesalahan. Jakarta: IAI.

Dewan Standar Akuntansi Keuangan. 2009. Standar Akuntansi Keuangan Entitas tanpa Akuntabilitas Publik. Jakarta: IAI.

Dewan Standar Akuntansi Keuangan. 2011. PSAK No. 45 (revisi 2011): Pelaporan Keuangan Entitas Nirlaba. Jakarta: IAI.

Elder, Randal, J., Beasley, Mark, S., Arens, Alvin ,A., Jusuf, A.A. 2011. Jasa Audit dan Assurance: Pendekatan Terpadu (Adaptasi Indonesia). Jakarta: Salemba Empat. 
Hall, James, A. 2009. Sistem Informasi Akuntansi. Jakarta: Salemba Empat.

Jusup, Al. Haryono. 2011. Dasar-dasar Akuntansi. Edisi 7. Yogyakarta: Bagian Penerbitan Sekolah Tinggi Ilmu Ekonomi YKPN.

Mulyadi. 2001. Sistem Akuntansi. Jakarta: Salemba Empat.

Nurhayati, S., dan Wasilah. 2009. Akuntansi Syari'ah di Indonesia. Jakarta: Salemba Empat.

Raco, J.R. 2010. Metode Penelitian Kualitatif: Jenis, Karakteristik, dan Keunggulannya. Jakarta: Grasindo.

Suharsaputra, U. 2012. Metode Penelitian: Kuantitatif, Kualitatif, dan Tindakan. Bandung: Refika Aditama.

Tim FE UIN Maulan Malik Ibrahim. 2014. Buku Pedoman Penulisan Skripsi. Malang.

Tofik, M. 2008. Membuat Aplikasi Akuntansi dengan Microsoft Office Excel 2007. Jakarta: Mediakita. 